\title{
BASE47 Gene Signature
}

National Cancer Institute

\section{Source}

National Cancer Institute. BASE47 Gene Signature. NCI Thesaurus. Code C121996.

A diagnostic system for high grade bladder cancer that can classify a tumor as one of two intrinsic subtypes (luminal or basal-like). This system is based on the expression profile of 47 genes. 